\title{
Levels of Lead in Blood and Hematocrit: Implications for the Evaluation of the Newborn and Anemic Patient
}

\author{
Joseph A. Kochen ${ }^{[29]}$ and Yigal Greener \\ Department of Pediatrics, Montefiore Hospital and Medical Center, and The Albert Einstein College of Medicine, \\ The Bronx, New York, USA
}

\section{Extract}

The uptake of lead was evaluated in vitro at hematocrits between $1 \%$ and $65 \%$ and at concentrations of lead in blood up to $1,000 \mu \mathrm{g} / 100 \mathrm{ml}$. Total erythrocyte volume was not a significant limiting factor in uptake of lead by erythrocytes at levels of lead in blood below $250 \mu \mathrm{g} / 100 \mathrm{ml}$ at hematocrit $25 \%$, below $375 \mu \mathrm{g} / 100 \mathrm{ml}$ at hematocrit $41 \%$, and below $500 \mu \mathrm{g} / 100 \mathrm{ml}$ at hematocrit $65 \%$. At a level of lead in blood of 80 $\mu \mathrm{g} / 100 \mathrm{ml}$, erythrocyte volume was not a limiting factor at hematocrits above $10 \%$. The diffusion of lead from a compartment which contained plasma or blood into another compartment which contained blood at hematocrits between $26 \%$ and $68 \%$ was studied. At equilibrium, the uptake of lead in blood was not reduced at the lower hematocrits.

Lead was injected into rats with hematocrits between $31 \%$ and $68 \%$, as a result of removal or transfusion of erythrocytes. Uptake of lead by blood did not correlate with hematocrit (significance of correlation coefficient $>0.05$ ). Rats were exposed to lead during gestation, lactation, and for a subsequent 4-month period. This resulted in a fourfold elevation of levels of lead in blood $(38.9 \pm 9.9 \mu \mathrm{g} / 100 \mathrm{ml}$ as compared with control values of $9.6 \pm 3.8 \mu \mathrm{g} / 100 \mathrm{ml})$. No correlation between hematocrit and levels of lead in blood could be established (correlation coefficient 0.20, $P>0.05$ ). Lead acetate in doses of $50 \mu \mathrm{g}$ and $75 \mu \mathrm{g}$ was injected into the yolk sacs of 4-day chick embryos and lead in blood and hematocrit levels were determined 14 days later. Increasing amounts of injected lead resulted in increasing levels of lead in blood $(9.0 \pm 2.7$ $\mu \mathrm{g} / 100 \mathrm{ml}$ in controls; $19.2 \pm 7.4 \mu \mathrm{g} / 100 \mathrm{ml}$ at $50 \mu \mathrm{g}$, and $32.5 \pm 11.7 \mu \mathrm{g} / 100 \mathrm{ml}$ at $75 \mu \mathrm{g}$ ). Despite the differences in levels of lead in blood, no relation between hematocrit and lead in blood was found (correlation coefficients of $0.25, P>0.05$ and 0.11 , $P>0.05$ ). Lead in maternal and newborn infant blood and hematocrit levels were determined. Despite the difference in hematocrit between infants $(64.3 \% \pm 9.8 \%)$ and mothers $(37.5 \% \pm 3.6 \%)$, there was no significant difference between levels of lead in infant blood $(19.1 \pm 7.6 \mu \mathrm{g} / 100 \mathrm{ml})$ and in maternal blood $(17.0 \pm 5.6 \mu \mathrm{g} / 100$ $\mathrm{ml}$ ). A positive correlation was found between levels of lead in infant and maternal blood (correlation coefficient of $0.58, P<0.01$ ). No correlation could be demonstrated between hematocrit and levels of lead in blood among infants (correlation coefficient $0.22, P>0.05$ ) or among mothers (correlation coefficient $0.24, P>0.05$ ). 


\begin{abstract}
Speculation
It has been assumed that the clinical evaluation of a given level of lead in blood requires correction for anemia. This was based on the assumption that the uptake of lead by the blood is limited by the reduced circulatory erythrocyte volume. This study has shown that the erythrocyte is present in considerable excess in the leaderythrocyte interaction within the commonly encountered range of hematocrit and levels of lead in blood. This would indicate that hematocrit variation has little influence on uptake of lead by blood and that correction of levels of lead in blood for anemia is unnecessary. The presence of similar levels of lead in blood for neonates and mothers indicates that an equilibrium exists between levels of lead in fetal and maternal blood which is unaffected by the difference in fetal and maternal hematocrits. This suggests that the extent of lead exposure and the lead burden in soft tissue may be similar in the mother and fetus.
\end{abstract}

\section{Introduction}

An evaluation of the lead content in soft tissue is a necessity if physicians are to deal effectively with the clinical risk factors of lead exposure and intoxication. It has been assumed that the concentration of lead in the blood reflects the level of lead in the soft tissues perfused by that blood $[7,15]$. Clinical experience indicates that this assumption is generally correct. It has also been assumed that in the presence of anemia, levels of lead in blood do not reflect contemporaneous exchangeable lead in the soft tissues, since the reduced circulatory erythrocyte volume limits the uptake of lead by the blood [9]. Because of this concern, it has become a dictum that the clinical evaluation of a given level of lead in blood requires correction to the value that would be expected if the patient's hematocrit were normal $[1,6,9,15,19]$. In the presence of a moderate degree of anemia, this may necessitate a significant correction of the level of lead in blood and a substantial upward reassessment of the lead burden in soft tissue. In view of the frequent association of anemia and lead intoxication [20], such correction may materially contribute to the number of patients in whom treatment is mandated.

The assumption that in anemia the volume of circulating erythrocytes may be a limiting factor in the capacity of the blood to transport lead is based on the observation that lead in blood is found mainly in association with erythrocytes $[3,8,14,16]$. Thus, it is well known that a reduction in the concentration of erythrocytes in a blood sample produces an almost stoichiometric reduction in concentration of lead in blood. However, on closer inspection, it is clear that the manipulation of pre-existing concentrations of lead in blood by changing the hematocrit provides no information relevant to an understanding of the relation between hematocrit and uptake of lead by blood. This study was undertaken to study this relation in vitro and in vivo and to examine the validity of the assumption that anemia is a limiting factor in the uptake of lead by the blood.

\section{Materials and Methods}

\section{In Vitro Studies}

Blood from healthy blood bank donors was collected from the antecubital vein into heparin, $10 \mathrm{U} / \mathrm{ml}(\mathrm{Na}$ heparin USP). The blood was used immediately after collection or stored at $4^{\circ}$ and used within $24 \mathrm{hr}$. No difference in uptake of lead by erythrocytes between fresh and stored blood was noted. Plasma was removed after centrifugation of blood $(10 \mathrm{~min}$ at $1000 \mathrm{rpm}$ in a Sorvall GLC-1 centrifuge [21]), and where necessary, plasma was added to blood to obtain a desired hematocrit. Blood specimens (2 ml) were brought to $37^{\circ}$ and a tracer dose of ${ }^{210} \mathrm{~Pb}$ or a tracer dose and a predetermined amount of lead acetate were added to raise the lead concentration in blood by a desired amount. The ${ }^{210} \mathrm{~Pb}\left(8.2 \mathrm{mCi} / \mathrm{mg} \mathrm{Pb}\left(\mathrm{NO}_{3}\right)_{2}\right.$ [22] $)$ was diluted with isotonic saline and a $100-\mu \mathrm{l}$ volume which contained $0.4 \mu \mathrm{Ci}$ was added per 2-ml blood specimen. Lead acetate (molecular weight 379.3 [23]) at various concentrations in isotonic saline was similarly added in a $100-\mu l$ volume. The blood was incubated at $37^{\circ}$ with periodic mixing and samples of $250 \mu \mathrm{l}$ were removed at intervals of 1-60 min for hematocrit and whole blood and plasma radioactivity measurements (4200 gamma counter [24]). For greater accuracy, the volumes of the 
blood and plasma specimens were determined by weight. The uptake of lead by erythrocytes was based on the following calculation:

$$
[\mathrm{Pb}]_{\text {erythr. }}=\frac{[\mathrm{Pb}]_{\text {hlood }}-[\mathrm{Pb}]_{\text {plasma }} \times(1-\text { hematocrit })}{\text { hematocrit }}
$$

The erythrocyte uptake of nonradioactive lead $[\mathrm{Pb}]_{\text {erythr. }}$ expressed as micrograms per $100 \mathrm{ml}$ or as percentage of uptake of lead added to the specimen, was calculated from the proportional uptake of ${ }^{210} \mathrm{~Pb}$.

A dialysis membrane system and Millipore filter system were used for lead diffusion studies. The dialysis membrane system consisted of a dialysis sac (cellulose dialyzer tubing [25]), which had been presoaked in isotonic saline for $24 \mathrm{hr}$. The sac contained $1 \mathrm{ml}$ plasma to which was added $200 \mu \mathrm{l}{ }^{210} \mathrm{~Pb}$ solution $(0.8 \mu \mathrm{Ci})$ and, where indicated, $100 \mu \mathrm{l}$ lead acetate at a concentration to raise the concentration of lead in plasma by $100-1,100 \mu \mathrm{g} / 100 \mathrm{ml}$. The dialysis sac was immersed in $10 \mathrm{ml}$ blood at various hematocrits and was incubated at $22^{\circ}$ for $3 \mathrm{hr}$ with constant mixing. Blood samples $(250 \mu \mathrm{l})$ were removed at 60-, 120-, and 180-min intervals, and the uptake of ${ }^{210} \mathrm{~Pb}$ was determined. This was expressed in terms of percentage of uptake of added lead. Equilibration was approached by $120 \mathrm{~min}$.

The Millipore filter system consisted of an equilibrium dialysis cell (2.5-ml total capacity [26]), in which the two compartments were separated by a Millipore membrane (plain, white, pore size $0.45 \mu$ ). One compartment contained $0.8 \mathrm{ml}$ blood at hematocrit $27 \%$, to which was added $150 \mu l{ }^{210} \mathrm{~Pb}$ solution $(0.6 \mu \mathrm{Ci})$, and, where indicated, $100 \mu \mathrm{l}$ lead acetate to raise the level of lead in blood by 125 or $250 \mu \mathrm{g} / 100 \mathrm{ml}$. A 1.6-ml sample of blood at hematocrit $27 \%$ or $55 \%$ was placed in the other compartment. The cell was incubated with mixing at $22^{\circ}$, and the blood was sampled $(250 \mu \mathrm{l})$ periodically for ${ }^{210} \mathrm{~Pb}$ determination. The results were expressed in terms of percentage of uptake of added lead. Equilibration was approached by 120 $\min$.

\section{In Vivo Studies}

Uptake of intraperitoneal lead. Rats (Wistar strain [27]), which weighed approximately $175 \mathrm{~g}$, were anesthetized with $\mathrm{Na}$ pentobarbital (Diabutal, $6 \mathrm{mg} / 100 \mathrm{~g}$ body wt) and the carotid artery and jugular vein were cannulated after heparinization ( $0.5 \mathrm{U} \mathrm{Na}$ heparin USP/g). Three or more rats were utilized per experiment. Four milliliters of arterial blood (in 2-ml aliquots) were collected, centrifuged, and the packed erythrocytes removed. The plasma was returned to the rat. The packed erythrocytes were infused via vein into another rat, and the third rat was used as a shamoperated animal. Hematocrits were periodically checked and after equilibration at $30 \mathrm{~min}, 1 \mathrm{ml}{ }^{210} \mathrm{~Pb}$ $(20 \mu \mathrm{Ci})$, and, where indicated, an additional $1 \mathrm{ml}$ lead acetate ( $50 \mu \mathrm{g}$ lead) was given by intraperitoneal injection. Arterial blood was sampled at 30, 60, 120, and $180 \mathrm{~min}$, and hematocrits and ${ }^{210} \mathrm{~Pb}$ levels were determined. Equilibration was approached by $120 \mathrm{~min}$. Results were expressed in terms of counts per minute per milliliter of blood.

Chronic lead exposure in rats. Rats were given $1 \%$ lead (in the form of lead acetate) in tap water as their sole source of drinking water before and during pregnancy. The dams were maintained on this regimen during suckling. After weaning, the litters were similarly maintained for a 4-month period. Concentrations of lead in blood, utilizing a flameless atomic absorption microtechnique [17], and hematocrit levels were periodically determined.

Chick embryo studies. Embryonated eggs (White Leghorn) were incubated at $38^{\circ}$ at high humidity, candled for viability, and on the 4th day, injected into the yolk sac with 50 or $75 \mu \mathrm{g}$ lead acetate $(250 \mu \mathrm{g} / \mathrm{ml})$. After 14 more days of incubation, $67 \%$ of control embryos, $52 \%$ of $50 \mu \mathrm{g}$ lead acetate-injected, and $34 \%$ of $75 \mu \mathrm{g}$ lead acetate-injected embryos survived. Embryos were removed rapidly, the omphalomesenteric blood vessels were transsected, and free flowing blood was collected for determinations of hematocrit and lead levels [17].

Maternal-neonate studies. Hematocrit and blood lead [17] levels were performed [28] on 35 randomly selected healthy, full term neonates and their mothers, within $24 \mathrm{hr}$ of birth.

\section{Results}

The kinetic data of lead uptake by human erythrocytes in vitro at varying lead levels at hematocrit $25 \%$ and $65 \%$ are shown in Figure 1. Table $I$ gives the percentage of uptake of lead by erythrocytes at hematocrits of 25, 41, and $65 \%$ after equilibration with increasing amounts of added lead. It is clear that the proportion of added lead taken up by erythrocytes is little influenced by variation in hematocrit at lead levels below $250 \mu \mathrm{g} / 100 \mathrm{ml}$. It is only at lead levels in the $1,000 \mu \mathrm{g} / 100 \mathrm{ml}$ range that the percentage of uptake of lead becomes proportional to the hematocrit, which indicates that the erythrocyte volume has be 


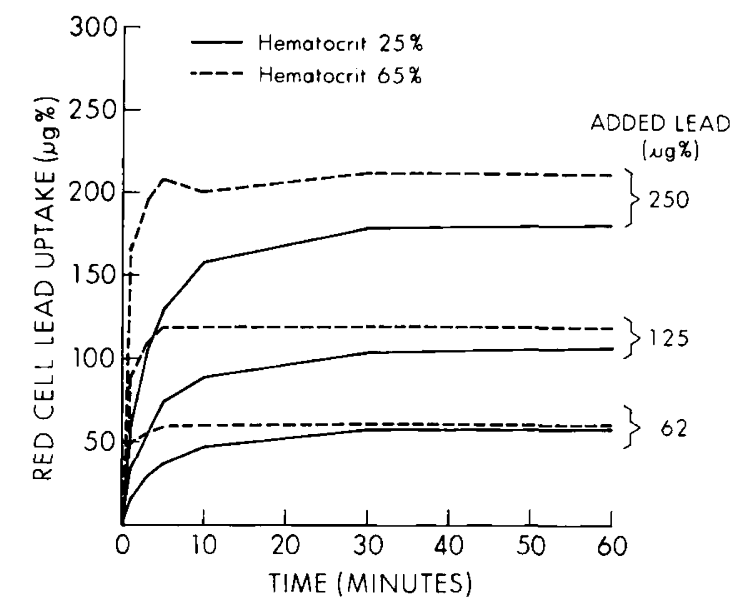

Fig. 1. Rate of lead uptake by human erythrocytes. A tracer dose of ${ }^{210} \mathrm{~Pb}$ and lead acetate were added to blood at hematocrit $25 \%$ and $65 \%$ to raise the level of lead in blood by 62,125 , and 250 $\mu \mathrm{g} / 100 \mathrm{ml}$. Lead uptake by erythrocytes in micrograms per 100 $\mathrm{ml}$ was determined at 1-, 3-, 5-, 10-, 30-, and 60-min intervals after incubation at $37^{\circ}$.

Table I. Lead uptake by erythrocytes at equilibration ${ }^{\mathrm{t}}$

\begin{tabular}{ccccc}
\hline \multirow{2}{*}{ Added lead, $\mu \mathrm{g} / 100 \mathrm{ml}$} & \multicolumn{3}{c}{ Lead uptake, $\%$} \\
\cline { 2 - 4 } & $25 \%$ Hematocrit & \multicolumn{4}{c}{ 41\% Hematocrit } & $65 \%$ Hematocrit \\
\hline $0^{2}$ & 88 & 88 & 86 \\
30 & 82 & 89 & 87 \\
60 & 77 & 86 & 88 \\
80 & 81 & 87 & 83 \\
100 & 70 & 80 & 79 \\
125 & 72 & 86 & 86 \\
188 & 76 & 85 & 88 \\
250 & 71 & 77 & 84 \\
375 & 63 & 79 & 83 \\
500 & 44 & 60 & 73 \\
1,000 & 23 & 39 & 59 \\
\hline
\end{tabular}

${ }^{1}$ Percentage of uptake by erythrocytes of a tracer dose of ${ }^{210} \mathrm{~Pb}$ and increasing amounts of lead acetate (expressed as $\mu \mathrm{g} / 100 \mathrm{ml}$ added lead). The lead was added to blood at hematocrits of 25 , 41 , and $65 \%$ and the percentage of uptake of the added lead was determined at equilibration after $60 \mathrm{~min}$ incubation at $37^{\circ}$. 2 Tracer amount of ${ }^{210} \mathrm{~Pb}$ only.

come the limiting factor in uptake of lead by erythrocytes.

The percentage of uptake of added lead by the cells after equilibration was determined in blood specimens with hematocrits which ranged between $1 \%$ and $65 \%$. The results (Fig. 2) show that at hematocrits above $10 \%$, the total erythrocyte volume is not a significant limiting factor in the uptake of lead by erythrocytes at blood lead levels of $80 \mu \mathrm{g} / 100 \mathrm{ml}$.

The uptake of lead by whole blood in vitro was studied by means of a dialysis system. In these experiments, the diffusion of lead from a compartment which contained plasma, across a dialysis membrane into a compartment which contained blood at various hematocrits, was determined. Equilibration was reached within $120 \mathrm{~min}$ and the percentage of uptake of lead by the blood was measured. The results of three representative experiments, over a wide range of levels of lead in plasma, are shown in Table II-A. The presence of a larger volume of erythrocytes did not enhance the diffusion of lead into the blood. Paradoxically, blood at lower hematocrits was consistently found to take up somewhat greater quantities of lead. An equilibrium dialysis cell system was used to determine the diffusion rate of lead from blood at hematocrit $27 \%$ across a Millipore filter $(0.45 \mu$ pore size) into blood at hematocrits of $27 \%$ and $55 \%$. The results of this study at two levels of lead in blood are shown in Table II-B. These data show that the diffusion of lead from blood at low hematocrit in one compartment, to blood at a similar or higher hematocrit in another compartment, is little influenced by the erythrocyte volume.

The relation between circulating erythrocyte volume and short term uptake of lead in blood in vivo was studied in anesthetized rats after the removal or administration of erythrocytes to achieve a wide range in hematocrits. The rats were then given intraperitoneal injections of either $(1)$ a tracer dose of $210 \mathrm{~Pb}$ or $(2)$ a similar tracer dose plus $50 \mu \mathrm{g}$ lead. Serial blood sampling showed an initial increase in the appearance of radioactivity in the blood which approached equilibra-

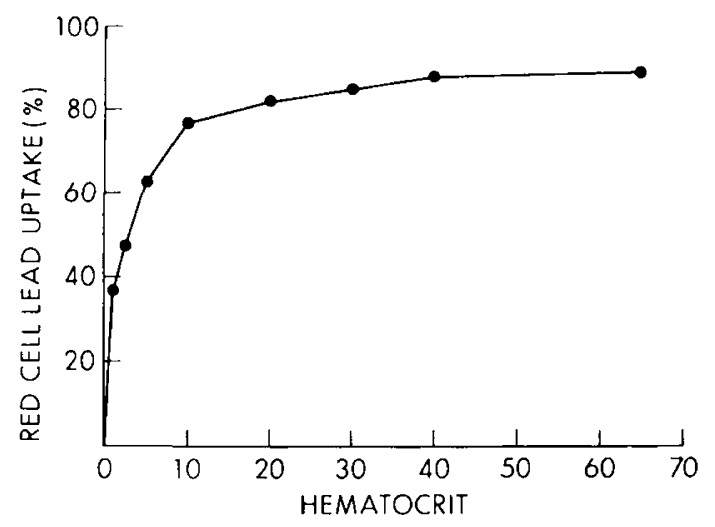

Fig. 2. Percentage of uptake of lead in blood by human erythrocytes at different hematocrits. A tracer dose of ${ }^{210} \mathrm{~Pb}$ and lead acetate were added to the blood at different hematocrits to raise the level of lead in blood by $80 \mu \mathrm{g} / 100 \mathrm{ml}$. The percentage of uptake by erythrocytes of the added lead was determined after a 60 -min incubation at $37^{\circ}$. 
Table II. Diffusion of lead into blood at various hematocrits

\begin{tabular}{lcc}
\hline \multicolumn{1}{c}{ Added lead, $\mu \mathrm{g} / 100 \mathrm{ml}$} & Hematocrit, $\%$ & $\begin{array}{c}\text { Uptake of } \\
\text { lead by } \\
\text { blood, } \%^{1}\end{array}$ \\
\hline $\begin{array}{l}\text { A. Dialysis membrane system }{ }^{2} \\
\text { Added lead, } 0^{3}\end{array}$ & 35 & 83 \\
& 70 & 74 \\
Added lead, $100 \mu \mathrm{g} / 100 \mathrm{ml}$ & 26 & 92 \\
& 46 & 81 \\
Added lead, $1,100 \mu \mathrm{g} / 100 \mathrm{ml}$ & 64 & 73 \\
B. Millipore filter $\mathrm{system}{ }^{4}$ & 31 & 45 \\
Added lead, $0^{3}$ & 43 & 44 \\
& 68 & 37 \\
Added lead, $125 \mu \mathrm{g} / 100 \mathrm{ml}$ & 27 & 17 \\
& 55 & 16 \\
Added lead, $250 \mu \mathrm{g} / 100 \mathrm{ml}$ & & 17 \\
\hline
\end{tabular}

${ }^{1}$ Uptake of lead by blood is expressed in terms of percentage of added lead.

${ }^{2}$ Diffusion of added lead from a plasma compartment, across a cellulose dialysis membrane, into a compartment which contained blood at different hematocrits.

3 Tracer amount of $210 \mathrm{~Pb}$ only.

${ }^{4}$ Diffusion of added lead from a compartment which contained blood (hematocrit $27 \%$ ), through a Millipore filter $(0.45 \mu$ pore size), into another compartment which contained blood at hematocrits $27 \%$ and $55 \%$.

tion levels by $120 \mathrm{~min}$. The range of radioactivity levels attained at equilibration are given in Table III. As indicated by the low correlation coefficients and values of $P>0.05$, no relation between circulating erythrocyte volume and the uptake of lead by the blood could be demonstrated, despite the wide range in hematocrit and ${ }^{210} \mathrm{~Pb}$ uptake.

A possible relation between hematocrit and levels of lead in blood under conditions of chronic lead exposure was investigated in rats exposed to $1 \%$ lead in their drinking water before and during pregnancy. Subsequently, the litters were similarly exposed to lead for a 4-month period. Hematocrit and values for lead in blood determined at the end of that period are given in Table IV-A. No significant difference in hematocrit between control and lead-treated rats was found. As was the case in the study of short term uptake of lead by blood, no relation between hematocrit and lead in blood was apparent in the chronically exposed rats (correlation coefficient of $0.20, P>0.05$ ).
The relation between hematocrit and uptake of lead by blood during embryonic development was studied in the chick. Chick embryos were exposed to lead by the injection of (1) $50 \mu \mathrm{g}$ lead acetate or (2) $75 \mu \mathrm{g}$ lead acetate into the yolk sac on the 4 th day of development. Levels of lead in blood and hematocrits were determined in 14 days later. As shown in Table IV-B, no significant difference in hematocrit could be found between the control and lead-injected embryos. The difference in the doses of administered lead resulted in a significant difference in levels of lead in blood $(P<$ 0.001 ). Again, despite the wide range in hematocrits and lead levels, no correlation was found to exist be-

Table III. Uptake of lead by blood in rats at various hemato. crits after intraperitoneal lead injection

\begin{tabular}{|c|c|c|c|}
\hline Amount of lead injected & $\begin{array}{l}\text { Hematocrit } \\
\text { range, } \%\end{array}$ & $\begin{array}{l}\text { Range of lead in } \\
\text { blood,1 } \\
\operatorname{cpm} \times 10^{3} / \mathrm{ml}\end{array}$ & $\begin{array}{l}\text { Correlation } \\
\text { coefficient }\end{array}$ \\
\hline $\begin{array}{l}\text { Tracer dose of }{ }^{210} \mathrm{~Pb} \\
(11)^{2}\end{array}$ & $31-68$ & $39-182$ & $\begin{array}{c}0.66 \\
(P>0.05)\end{array}$ \\
\hline $\begin{array}{l}\text { Tracer dose of }{ }^{210} \mathrm{~Pb} \\
\text { plus } 50 \mu \mathrm{g} \text { lead } \\
(11)^{2}\end{array}$ & $30-57$ & $3.1-11.2$ & $\begin{array}{c}0.50 \\
(P>0.05)\end{array}$ \\
\hline
\end{tabular}

1 After equilibration at 120 min after injection.

2 Number of animals.

Table IV. Relation of hematocrit to levels of lead in blood in vivo ${ }^{2}$

\begin{tabular}{|c|c|c|}
\hline & Hematocrit, $\%$ & $\begin{array}{l}\text { Lead in blood, } \\
\mu \mathrm{g} / 100 \mathrm{ml}\end{array}$ \\
\hline \multicolumn{3}{|l|}{ A. Rats $^{2}$} \\
\hline Control (12) & $\begin{array}{c}42.6 \pm 3.5 \\
(31-49)\end{array}$ & $\begin{array}{c}9.6 \pm 3.8 \\
(5-13)\end{array}$ \\
\hline Lead-exposed (37) & $\begin{array}{c}41.6 \pm 3.4 \\
(34-51)\end{array}$ & $\begin{array}{c}38.9 \pm 9.9 \\
(21-64)\end{array}$ \\
\hline \multicolumn{3}{|l|}{ B. Chick embryos ${ }^{3}$} \\
\hline Control (24) & $\begin{array}{c}34.9 \pm 4.4 \\
(29-43)\end{array}$ & $\begin{array}{c}9.0 \pm 2.7 \\
(4-13)\end{array}$ \\
\hline Lead acetate, $50 \mu \mathrm{g}(77)$ & $\begin{array}{c}39.2 \pm 5.4 \\
(24-50)\end{array}$ & $\begin{array}{c}19.2 \pm 7.4 \\
(6-42)\end{array}$ \\
\hline Lead acetate, $75 \mu \mathrm{g}(55)$ & $\begin{array}{c}37.3 \pm 5.0 \\
(27-47)\end{array}$ & $\begin{array}{c}32.5 \pm 11.7 \\
(14-62)\end{array}$ \\
\hline \multicolumn{3}{|l|}{ C. Human ${ }^{4}$} \\
\hline Mothers (35) & $\begin{array}{c}37.5 \pm 3.6 \\
(31-46)\end{array}$ & $\begin{array}{c}17.6 \pm 5.6 \\
(8-34)\end{array}$ \\
\hline Newborn infants (35) & $\begin{array}{c}64.3 \pm 9.8 \\
(46-86)\end{array}$ & $\begin{array}{c}19.1 \pm 7.6 \\
(12-47)\end{array}$ \\
\hline
\end{tabular}

1 Values are expressed as means $\pm s D$; range is shown within parentheses.

${ }^{2}$ Addition of $1 \%$ lead into drinking water for 4-5 months.

${ }^{3}$ Lead acetate injected into yolk sac on 4 th day, blood sampled on 18th day.

"Random selection of full term healthy newborn infants and mothers within $24 \mathrm{hr}$ of birth. 
tween hematocrit and levels of lead in blood at the $50-\mu \mathrm{g}$ lead acetate dose (correlation coefficient of 0.24 , $P>0.05$ ) or at the $75-\mu \mathrm{g}$ dose (correlation coefficient of $0.11, P>0.05)$.

The widely divergent hematocrits between mother and human fetus offer a unique opportunity to determine whether hematocrit plays a limiting role in uptake of lead by blood in man. Hematocrit and levels of lead in blood were determined in 35 neonates and their mothers within $24 \mathrm{hr}$ of birth. The results of this study are found in Table IV-C. Notwithstanding the difference in mean hematocrit levels between infants $(64.3 \%)$ and mothers $(37.5 \%)$, the mean levels of lead in blood of $19.1 \mu \mathrm{g} / 100 \mathrm{ml}$ in the infants and 17.6 $\mu \mathrm{g} / 100 \mathrm{ml}$ in the mothers showed no statistically significant difference. No correlation was evident between hematocrit and levels of lead in blood among the infants (correlation coefficient of $0.22, P>0.05$ ) or the mothers (correlation coefficient of 0.24, $P>0.05$ ). However, a positive correlation was found between levels of lead in infant and maternal blood (correlation coefficient of $0.58, P<0.01$ ).

\section{Discussion}

The manner in which lead is associated with the erythrocyte is not well understood. It has been assumed that lead interacts with the erythrocyte membrane $[2,8]$; however, other observations suggest that lead is bound predominantly to the cell contents [4]. The present study is in agreement with previous findings $[3,8,14]$ that most of the lead introduced into the plasma becomes rapidly attached to the erythrocyte and that equilibrium is attained within 5-10 min (Fig. 1). The more rapid equilibration at higher hematocrits is in keeping with the observation that the initial reaction velocity is dependent upon the total volume of erythrocytes present [8]. The nature of the reaction remains open to speculation. The small variation in the proportional uptake of lead by erythrocytes over a wide range of values for lead in blood (Table I) and hematocrits (Fig. 2), indicates that, at levels commonly encountered clinically, the erythrocyte is a reactant present in considerable excess. When the data in Table $I$ is considered in terms of concentration of lead in erythrocytes and blood, it is apparent that higher concentrations of lead in erythrocytes are found at lower hematocrits. Thus, at a levels of lead in blood in the 275 $\mu \mathrm{g} / 100 \mathrm{ml}$ range, at hematocrit $25 \%$ the lead concentration in erythrocytes is $772 \mu \mathrm{g} / 100 \mathrm{ml}$; at hematocrit $4.1 \%$ the lead concentration in erythrocytes is $526 \mu \mathrm{g} /$
$100 \mathrm{ml}$; and at hematocrit $65 \%$ the lead concentration in erythrocytes is $377 \mu \mathrm{g} / 100 \mathrm{ml}$. This increment in lead concentration in erythrocytes as an inverse function of hematocrit is a reflection of the high avidity of the erythrocyte for lead at less than saturation levels. It has been shown previously that saturation levels for erythrocytes are attained in the $1000 \mu \mathrm{g} / 100 \mathrm{ml}$ range $[3,14]$. In this study, concentration of lead in erythrocytes ceases to be affected by hematocrit variation at levels of lead in blood in the $1,000 \mu \mathrm{g} / 100 \mathrm{ml}$ range. Thus, at a level of lead in blood in the $1,000 \mu \mathrm{g} / 100$ $\mathrm{ml}$ range, at hematocrit $25 \%$, the lead concentration in erythrocytes is $967 \mu \mathrm{g} / 100 \mathrm{ml}$; at hematocrit $41 \%$ the lead concentration in erythrocytes is 999 $\mu \mathrm{g} / 100 \mathrm{ml}$; at hematocrit $65 \%$ the lead concentration in erythrocytes is $955 \mu \mathrm{g} / 100 \mathrm{ml}$. These three concentrations of lead in erythrocytes are comparable, irrespective of hematocrit variation. It is clear from this data that a stoichiometric relation between hematocrit and lead uptake only exists at saturation levels for erythrocytes in the $1,000 \mu \mathrm{g} / 100 \mathrm{ml}$ range. At levels of lead in blood and hematocrit levels encountered commonly in clinical medicine, the high avidity and the unsaturated state of the erythrocyte with respect to lead compensates for any variation in hematocrit.

The conclusion that the erythrocyte appears to be markedly unsaturated with respect to lead and that erythrocyte volume is not a limiting factor in the uptake of lead in blood was borne out by diffusion studies utilizing two different systems. One diffusion system was based on dialysis, and the other on diffusion through $0.45-\mu$ pores in a Millipore membrane. These systems were selected because they may represent simplified models of the process of lead uptake by blood in vivo.

In the dialysis studies (Table II-A), the diffusion of lead from a plasma compartment into blood at different hematocrits resulted in a proportional lead uptake at equilibrium, which was similar to that found when lead was added directly to the blood. A notable finding was that the presence of a lower hematocrit did not result in a reduced uptake of lead by the blood. The obervation that plasma lead is dialyzable indicates that at least part of the lead is in a nonprotein bound form. This is in keeping with the suggestion that lead may form a lead-phosphate complex in the plasma [8].

The use of the Millipore system (Table II-B) demonstrated that variation in hematocrit does not affect values for lead in blood attained at equilibration when lead diffuses from one blood compartment into another. This movement of lead from one compartment 
to another occurred without depletion of the lead content of the plasma phase, which indicates that a complex dynamic equilibrium exists between the plasma and erythrocytes in both compartments.

The in vivo study analogous to the in vitro diffusion study was that in which lead was injected into the intraperitoneal compartment of rats and its diffusion into the blood at different hematocrits was determined. Not unexpectedly, a wide range in values for uptake of lead by blood was observed at both dosage levels of lead (Table III). However, this variation in equilibrium values for lead in blood showed no relation to the hematocrits of rats, as indicated by the low correlation coefficients. Thus, short term equilibration studies in vitro and in vivo demonstrated no correlation between erythrocyte volume and lead uptake in the range of values commonly seen in clinical medicine.

Inasmuch as the relation between hematocrit and lead uptake may be different after slow physiologic absorption, rats were studied after exposure to a standard oral intake of lead over a period of many months. This resulted in levels of lead in blood which ranged from 21 to $64 \mu \mathrm{g} / 100 \mathrm{ml}$, as compared with the 5 to 13 $\mu \mathrm{g} / 100 \mathrm{ml}$ range for controls (Table IV-A). The finding that no correlation could be established between levels of lead in blood and hematocrits indicates that the conclusions drawn from the short term in vitro and in vivo equilibration studies were applicable to conditions more comparable with those present in man. This was further corroborated by the observation that there was no correlation between hematocrits and levels of lead in blood in chick embryos 14 days after the administration of standardized doses of lead into the yolk sac (Table IV-B). These experiments extended this study into the lead range where pronounced central nervous system toxicity and mortality due to lead was found [12].

Studies on experimental animals have shown that lead moves into the circulation of the placenta and then into the fetus as though no barrier existed between the blood of the mother and the blood of the fetus [5]. The lead diffusion experiments utilizing the Millipore membrane interposed between blood of low hematocrit and blood of high hematocrit are analogous to the fetomaternal situation. The findings of the diffusion experiments suggest that, despite the marked difference in hematocrits between maternal and fetal blood, concentrations of lead in blood should be similar in both circulations. This would obviously not be the case if the hematocrit were a determining factor in uptake of lead by blood. The mother-fetus combination may thus be an "experiment in nature" which would permit a determination whether hematocrit and circulating erythrocyte volume affect lead levels in human blood. The results of hematocrit and measurements of lead in blood of the infants and mothers in this study show clearly the expected difference in hematocrits, virtually no difference in mean levels of lead in blood, and a positive correlation between lead levels in infant and maternal blood. No correlation was found between hematocrit and levels of lead in blood among infants or mothers (Table IV-C). The observation of similar levels of lead in blood of mothers and infants is in accord with several recent reports $[10,18]$. It is reasonable to conclude from these observations that an equilibrium exists between the maternal and fetal circulations with respect to lead which is unaffected by the difference in fetal and maternal hematocrits. Given the same lead levels in blood in the mother and fetus and the proposition that correction for hematocrit variation is unnecessary, it may be concluded that the extent of lead exposure and lead burden in soft tissue is similar in the mother and fetus.

This study has demonstrated that, within the clinical range of values, the erythrocyte is generally present in considerable excess in the lead-erythrocyte interaction and that hematocrit variation has little influence on uptake of lead by blood. It may be concluded that there is no basis for correction of levels of lead in blood for anemia, or for that matter, erythrocytosis. Under circumstances in which the levels of lead in blood are exceptionally high, correction for anemia would be of small additional consequence in the evaluation of the clinical risk factors. Persistence in the correction of lead values in blood may result in unnecessary hospitalization and chelation therapy. In a recent report, correction for anemia resulted in an increase in levels of lead in blood to values above 60 $\mu \mathrm{g} / 100 \mathrm{ml}$ in $25 \%$ for children with lead exposure [11]. In particular, unnecessary correction may be misleading in patients with anemia due to other causes. Glucose 6-phosphate dehydrogenase deficiency was recently described as being associated with elevated concentrations of lead in blood [13]. However, this apparently was the case only after the observed values for lead in blood, which were not significantly different from the nondeficient controls, had been corrected for anemia.

The American Academy of Pediatrics [1], the United States Public Health Service [19], the National Research Council [15], a recent textbook of pediatrics 
[6], and others have advocated the correction of levels of lead in blood for anemia. This study questions the scientific basis and advisability of such a procedure.

\section{Summary}

Levels of lead in blood provide the best means for assessing lead intoxication. It is generally accepted that the clinical evaluation of a given level of lead in blood requires correction for anemia. This is based on the assumption that the capacity of the blood to carry lead is limited by the volume of erythrocytes. The following results question the validity of this assumption at hematocrit and lead levels in the clinical range. (1) The uptake of lead by erythrocytes was determined in vitro at varying hematocrit and lead levels. Erythrocyte volume was not a limiting factor in lead uptake at hematocrits above $10 \%$ and lead levels below $250 \mu \mathrm{g} /$ $100 \mathrm{ml}$. (2) Plasma which contained lead was dialyzed against blood at various hematocrits. Similarly, the diffusion of lead from a compartment which contained blood into another compartment which contained blood at different hematocrits was examined. At equilibrium no increased uptake of lead was found at higher hematocrits. (3) Rats with varying hematocrits because of bleeding or transfusion were given intraperitoneal injections of lead. Subsequent uptake of lead by blood did not correlate with hematocrit. (4) Rats were exposed to $1 \%$ lead in their drinking water for 4 months. No correlation between hematocrit and lead levels was found. (5) Lead was injected into yolk sacs of chick embryos. No relation between hematocrit and blood lead was found after 14 days. (6) No significant difference could be found between levels of lead in maternal and newborn infant blood despite the marked difference in hematocrit between the two groups. It may be concluded that anemia is not a limiting factor in uptake of lead by blood and that correction for low hematocrit is unnecessary and may result in an incorrect estimation of the lead burden of soft tissue.

\section{References and Notes}

1. American Academy of Pediatrics Subcommittee on Accidental Poisoning: Prevention, diagnosis, and treatment of lead poisoning in children. Pediatrics, 44: 291 (1969).

2. Aub, J. C., Fairhale, L. T., Minot, A. S., And Reznikoff, P.: In: Lead Poisoning (The Williams \& Wilkins Co., Baltimore, 1926).

3. Bambach, K., Kehoe, R. A., and Logan, M. A.: The plasmacell partition of blood lead. J. Pharmacol., 76: 326 (1942).
4. Barltrop, D., AND SMITH, A.: Interaction of lead with erythrocytes. Experientia, 27: 92 (1971).

5. Baumann, A.: Über die Durchlässigkeit der Placenta für Blei. Arch Gynäk., 153: 584 (1933).

6. Chisolm, J. J., Jr.: Lead poisoning. In: H. L. Barnett and A. H. Einhorn: Pediatrics, Ed. 15, p. 540 (Appleton-CenturyCrofts, New York, 1972).

7. Chisolm, J. J., JR.: Increased lead absorption: Toxicological considerations. Pediatrics, $48: 349$ (1971).

8. Clarkson, T. W., and Kench, J. E.: Uptake of lead by human erythrocytes in vitro. Biochem. J., 69: 432 (1958).

9. Davies, T. A. L., AND RAINSFORD, S. G.: Reporting blood lead values. Lancet, 2: 834 (1967).

10. Harris, P., AND Holley, M. R.: Lead levels in cord blood. Pediatrics, 49: 606 (1972).

11. Kammholz, L. P., Thatcher, L. G., Blodgett, F. M., And Goon, T. A.: Rapid free erythrocyte protoporphyrin test for lead. Pediatrics, 50: 625 (1972).

12. Kochen, J., and Hirano, A.: Neurotoxic effects of lead in the chick embryo (Abstract). Pediat. Res., 6: 421 (1972); J. Lab. Invest., in press.

13. McIntire, M. S., ANd ANgle, C. R.: Air lead: Relation to lead in blood of Black school children deficient in glucose-6-phosphate dehydrogenase. Science, 177: 520 (1972).

14. Mortenson, R. A., And Kellogg, K. E.: The uptake of lead by blood cells as measured with a radioactive isotope. J. Cell. Compr. Physiol., 23: 11 (1944).

15. National Academy of Sciences: Airborne Lead in Perspective, (National Academy of Sciences, Washington, D. C., 1972).

16. Robinson, M. J., Karpinski, F. E., ANd Brieger, H.: The concentration of lead in plasma, whole blood and erythrocytes of infants and children. Pediatrics, 21: 793 (1958).

17. Rosen, J. F., ANd Trinidad, E. E.: The microdetermination of blood lead in children by flameless atomic absorption: The carbon rod atomizer. J. Lab. Clin. Med., 80: 567 (1972).

18. SCANLON, J.: Umbilical cord blood lead concentration. Amer. J. Dis. Child., 121: 325 (1971).

19. United States Public Health Service: Medical aspects of childhood lead poisoning (Statement approved by Surgeon General). Pediatrics, 48: 464 (1971).

20. Watson, J. R., Decker, E., and Lichtman, H.: Hematologic studies of children with lead poisoning. Pediatrics, 21: 40 (1958).

21. Ivan Sorvall, Inc., Norwalk, Conn.

22. New England Nuclear Corporation, Boston, Mass.

23. J. T. Baker Chemical Co., Phillipsburg, N. J.

24. Nuclear-Chicago Corporation, Des Plaines, Ill.

25. Model 4465-A2, Arthur H. Thomas Co., Philadelphia, Penn.

26. Chemical Rubber Company, Cleveland, Ohio.

27. Carworth Farms, New City, N. Y.

28. With the technical assistance of $\mathbf{P}$. Shaffer and $\mathbf{E}$. Trinidad.

29. This research was supported by a grant from The United Cerebral Palsy Research and Educational Foundation, Inc.

30. Requests for reprints should be addressed to: Joserp $A$. Kochen, M.D., Department of Pediatrics, Montefiore Hospital and Medical Center, 111 E. 210th St., The Bronx, New York.

31. Accepted for publication July 12, 1973. 